\title{
GLYPHOSATE AND AMINOMETHYLPHOSPHONIC ACID IN POPULATION OF AGRICULTURAL FIELDS: HEALTH RISK ASSESSMENT OVERVIEW
}

\author{
LEYVA-Soto, L. A. ${ }^{1}$ - BALDERRAMA-CARMONA, A. P..$^{2 *}$ - MORAN-PALACIO, E. F. ${ }^{2}$ - DiAZ- \\ TENORIO, L. M. ${ }^{1}$ - GORTARES-MOROYOQUI, P. ${ }^{1}$ \\ ${ }^{1}$ Departamento de Biotecnología y Ciencias Alimentarias, Instituto Tecnológico de Sonora \\ 5 de febrero 818 Sur, Colonia Centro, C.P. 85000, Cd. Obregón, Sonora, México \\ ${ }^{2}$ Departamento de Ciencias Químico Biológicas y Agropecuarias, Universidad de Sonora, \\ Unidad Regional Sur, Lázaro Cárdenas 100, Colonia Francisco Villa, C.P. 85880, Navojoa, \\ Sonora, México \\ *Corresponding author \\ e-mail:pabal@navojoa.uson.mx; phone: +52-642-425-9969 \\ (Received 23 ${ }^{\text {rd }}$ May 2018; accepted $17^{\text {th }}$ Jul 2018)
}

\begin{abstract}
Glyphosate is the most used herbicide in the world. In 2015, it was declared as probably carcinogenic to humans by the International Agency for Research on Cancer. In Valle del Mayo, Sonora, México, more than $20000 \mathrm{~L}$ of this herbicide are sprayed per year. Therefore, the objective of this work was to assess human health risk associated with exposure of water contaminated with glyphosate and aminomethylphosphonic acid (AMPA) on a population in agricultural fields of Valle del Mayo communities. A cohort study was performed among the exposed populations; glyphosate and AMPA concentrations were measured in water drains, private wells, and groundwater by high-performance liquid chromatography (HPLC). Health risk was subsequently assessed obtaining a hazard ratio. Concentrations for glyphosate were lower than $5 \mu \mathrm{g} \mathrm{L}^{-1}$ while those for AMPA were 15-342.5 $\mu \mathrm{g} \mathrm{L}^{-1}$ or $\mu \mathrm{g} \mathrm{g}^{-1}$. The results showed a statistical correlation among people consuming water from private wells with diabetes $(p \leq 0.03)$ and hypertension $(p \leq 0.004)$. The resulting risk assessment hazard ratio was 0.22 for agricultural laborers and 0.39 for brick makers when an acceptable daily dose of $0.03 \mathrm{mg} \mathrm{kg}^{-1} \mathrm{~d}^{-1}$ was taken into account, indicating a potential health risk.
\end{abstract}

Keywords: herbicide exposure, occupational exposure, HPLC, AMPA

\section{Introduction}

The yield has been reduced in agricultural practices all over the world due to weeds, thus the reason for using herbicides. Glyphosate (N-Phosphonomethylglycine) is a systemic non-selective post-emergent herbicide, whose average soil life, fluctuates from 2 to 197 days, resisting the environment for up to three years (Chufan et al., 2014; Quarles, 2012). Its use has been recorded in at least 130 countries, commercially known as Faena ${ }^{\circledR}$, Roundup ${ }^{\circledR}$, Dicamba, among others (Dill et al., 2010; Cattani et al., 2014) even more 750 products contain glyphosate as active ingredient (NPIC, 2015). Glyphosate is an herbicide for residential, urban and agricultural everyday use around the world, its formulations are the most sold at world level, of which 6.1 thousand millions of $\mathrm{kg}$ of glyphosate have been applied only in the last decade (Benbrook, 2016). The mechanism of glyphosate on plants is by the shikimate metabolic pathway. It is a chemical highly water-soluble; in the soil it degrades rapidly to sarcosine acid and aminomethylphosphonic acid (AMPA), the last one is the main metabolic intermediary (Amrhein et al., 1980). 
International disagreements exist with respect to the classification of glyphosate as carcinogenic. According to the International Agency for Cancer Research (IARC), glyphosate is "probably carcinogenic for human beings" while for the United States Environmental Protection Agency (USEPA) "it is probably not carcinogenic". However, exists scientific research with evidence that glyphosate produces: infertility, kidney problems (USEPA, 2015), endocrine disruption (Gasnier et al., 2009), apoptosis, cytotoxicity, and neurotoxic oxidative effects (Chaufan et al., 2014; Cattani et al., 2014; $\mathrm{Ma}$ and Li, 2015). It has also been related to minor illnesses, such as autism, Alzheimer, Parkinson, anxiety disorders, osteoporosis, inflammatory intestinal disease, osteomalacia, cholestasis and thyroid dysfunction (Samsel and Seneff, 2015). Also, has been proved that AMPA causes genotoxicity (Mañas et al., 2009; IARC, 2016).

Exposure to glyphosate and its degrading products in air, soil, and water is unavoidable, mainly in populations close to agricultural fields. In these places, aerial and mechanical pesticide applications are constant (up to 45 times per year). Despite people are not exposed directly to these chemical agents, they could be in contact with glyphosate or AMPA either by occupation or diet, which could be regarded as a human health risk. Occupational exposure is considered of a greater risk (Nawaz et al., 2014; Parrón et al., 2014; Angeli et al., 2015).

Valle del Mayo is one of the largest agricultural producers in northwestern Mexico where an extensive irrigation system provides water to more than 93000 ha of cultivation (INEGI, 2017). The most widely used herbicide is glyphosate at $1 \%$ in canals while a mixture of glyphosate with Tordon is used at $1.5 \%$ in drains. In total, more than $20000 \mathrm{~L}$ of glyphosate is sprayed in this region per year just to eliminate grass in irrigation canals and drains. In Mexico, no regulations exist for glyphosate while a regulation project proposed a permissible concentration of $100 \mu \mathrm{g} \mathrm{L}^{-1}$ (PROY NOM-250-SSA1-2014); although, it is not officially approved yet.

Most of the agricultural laborers of Valle del Mayo live next to the irrigation drains for generations. They do not have a public water supply in their homes and municipality authorities sends trucks to deliver water to these places; however, delivery delays. Some houses have private wells built a few meters from the irrigation drains, which might imply infiltration of contaminants. Additionally, in most of the housing units, kitchens are found outdoors, which could cause food contamination and skin exposure to the applied herbicides. Due to this problem, the objective of this work was to assess health risk associated to exposure of contaminated water with glyphosate and AMPA in populations of agricultural fields in the communities of Valle del Mayo, Sonora, Mexico.

\section{Materials and methods}

\section{Geographical location of the study}

It is located in Valle del Mayo (26 $31^{\prime} 54^{\prime \prime} \mathrm{N} 109^{\circ} 38^{\prime} 02^{\prime}$ W) in the municipalities of Navojoa, Etchojoa, and Huatabampo in the southern part of the State of Sonora in northwestern Mexico. The communities close to irrigation canals were selected by cartographic research related to the Irrigation District of Rio Mayo. The following criterions were considered for the selection: (1) Housing of participants less than $50 \mathrm{~m}$ from an irrigation canal or drain; (2) Drains or canals with weed problems; (3) Herbicide applied at least twice a year; (4) Difficult access to drinking water; (5) Communities with private wells; (6) People working close to drains and canals. 


\section{Assessment of health risk by glyphosate and aminomethylphosphonic acid}

\section{Hazard identification}

Environmental samples collection. The points were selected in areas were herbicide formulated with $1 \%$ of N-Phosphonomethylglycine at $99 \%$ and $0.001 \%$ of adherent in canals and a mix of $1.5 \%$ of N-Phosphonomethylglycine at $99 \%$ and tordon, and $0.001 \%$ of adherent in drains. The sample collection was carried out in irrigation drains or canals close to communities with private wells were the application of glyphosate is constant. GPS coordinates are the follow: Tres Carlos 26.919385, -109.512457, Saucobe 26.958041, -109.498360, Colonia Soto 26.907112, -109.602550, Sebampo 26.878628, 109.571211, La Esquina 26.804662, -109.716644, Ramal 26.792826, -109.767667, Moroncarit 26.734392, -109.614932, Entronque 26.860334, -109.636900 and Huatabampo 26.826744, -109.650587 (Fig. 1).

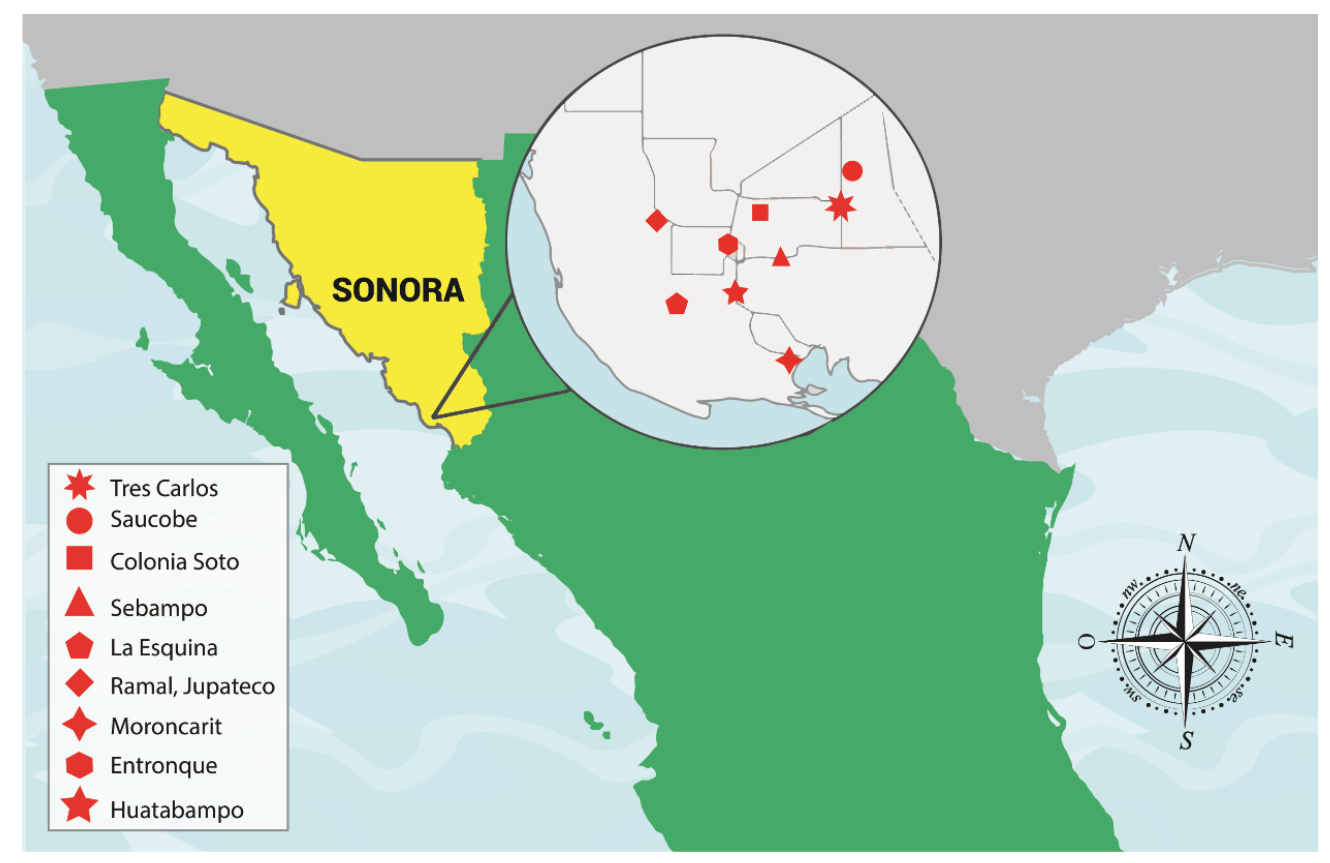

Figure 1. Location of the selected communities for the risk assessment study of glyphosate and AMPA in Valle del Mayo, Sonora, Mexico

The samples were collected in sterile $100 \mathrm{~mL}$ polypropylene wide-mouth flasks. Drain and/or canal water was taken during glyphosate application (when the brushwood was grown and the application was necessary); is for this reason the samples per place are different. In the case of soil, sediment or drain/bottom canal was also sampled where water was previously collected with a difference of one month, collecting approximately $200 \mathrm{~g}$ following standard methods. Well water samples were taken approximately every two months and always after herbicide application. Both were collected in the selected points from February 2016 to May 2017. All samples were transported in a cooler to the laboratory and preserved at $-80{ }^{\circ} \mathrm{C}$ until analyses were performed.

HPLC analytic method. The method was adapted and modified for water and soil (Olivo et al., 2015; Peruzzo et al., 2008). Water and soil samples were purified by filtration through a cellulose acetate membrane of $0.45 \mu \mathrm{m}$ (MF-Millipore ${ }^{\mathrm{TM}}$ ). Soil samples purification was performed by duplicate extraction shaking $15 \mathrm{~g}$ of the sample 
with $25 \mathrm{~mL}$ of $\mathrm{KH}_{2} \mathrm{PO}_{4} 0.1 \mathrm{M}$ for 15 min and subsequently filtered through Whatman ${ }^{\mathrm{TM}}$ paper (Sigma-Aldrich, MO. U.S.A.) and centrifuged at $3500 \mathrm{rpm}$ for $10 \mathrm{~min}$. The obtained extract was filtered following the protocol for water samples (Peruzzo et al., 2008).

Derivatization was performed mixing 3-mL purified sample and 2-mL FMOC-Cl (0.005 M) (23186 Sigma-Aldrich, MO, U.S.A.) prepared with chloroform (650498 Sigma-Aldrich, MO, U.S.A.). It was maintained for $45 \mathrm{~min}$ avoiding radiation. After the reaction, 3-mL methyl chloride (270997 Sigma-Aldrich, MO, U.S.A.) were added to remove excess of FMOC-CL; subsequently, the supernatant was filtered using SPE polymeric columns (Strata-X ${ }^{\mathrm{TM}}$, Torrance, CA, U.S.A.) (Olivo et al., 2015). The collected filtered solution was taken for high-performance liquid chromatography (HPLC) (Agilent 1200 series, Santa Clara, CA, U.S.A.).

Modifications to chromatographic conditions were established as follows: Column Agilent C18 $250 \times 4.6 \mathrm{~mm}$, the injection volume of $20 \mu \mathrm{L}$, water flux mobile phase $1 \mathrm{Ml}$ $\min ^{-1}$, UV $240 \mathrm{~nm}$ and FL excitation 266 emission 315. Total analysis time per each sample was 30 minutes.

Method validation. The calibration curves were performed using one blank run and different aqueous concentration patterns of glyphosate and AMPA. The concentrations tested were from 5-25 and 15-90 $\mu \mathrm{g} \mathrm{L}^{-1}$ for glyphosate and AMPA respectively.

Glyphosate and aminomethylphosphonic acid concentrations in vegetables washed with contaminated water with herbicides. It is possible to estimate the risk in vegetables based on the risk developed for water (Haas et al., 1999; Shuval et al., 2007; Mota et al., 2009). Taking into account that the population in the Mayo Valley uses irrigation water from drains for domestic activities, in this case, wash vegetables before eating them; the volume of water retained by the most consumed vegetables was calculated applying Equation 1:

$$
C V=C x V r
$$

where $C V$ is the concentration in vegetables $\left(\mathrm{mg} \mathrm{g}^{-1}\right) ; C$, is the concentration of herbicide in water, and $V r$, is the volume of water retained in the vegetable. Considered roughtexture vegetables, which have been reported to retain approximately $0.108 \mathrm{~mL} \mathrm{~g}^{-1}$ and $0.0036 \mathrm{~mL} \mathrm{~g}^{-1}$ the smooth ones (Mota et al., 2009).

\section{Exposure evaluation}

Cohort/population study. An agricultural health study was developed, which included individuals located in areas close to drains and who made use of water for domestic activities and consumption.

Population size. A total of 586 persons lived at $\leq 50 \mathrm{~m}$ from irrigation drains in Valle del Mayo, which was estimated visiting populations. Population size was estimated with a margin of error of $10 \%$ and confidence level of $90 \%$ using the statistical software Epi Info 7.2 (CDC, 2017).

Exposure estimation. Socioeconomic, consumption, health and symptomatology surveys were applied to the sampling populations, estimating water and food consumption patterns (portion size and frequency). The population was characterized in age, sex, occupation, schooling, socioeconomic condition, feeding, and water consumption groups.

Three exposure scenarios were established for the analysis: (a) Participants drink water from private wells close to irrigation drains (always/never); (b) Days accumulated to 
which they are exposed to (if well water is used some days or always); (c) If participants are present during herbicide application (aerial exposure).

The levels of intensity were estimated using data from the questionnaires. Aliments with higher frequency were assessed and associated with glyphosate exposure.

\section{Toxicity assessment}

The dose of a potential toxin for the human body by contact with contaminants (water, soil) should indicate the amount of the chemical substance ingested per kilogram of corporal weight per day $\left(\mathrm{mg} \mathrm{kg}^{-1} \mathrm{day}^{-1}\right)$. To calculate the dose for each source, Equation 2 (USEPA, 1989; CIDA, 2009) was used:

\section{Dose (soil, water, food ingestion) $=\mathrm{C} \times \mathrm{I} \times \mathrm{AF} \times \mathrm{Dh} \times \mathrm{Dd} \times \mathrm{Dw} / \mathrm{BW} \times 16$}

Where $\mathrm{C}\left(\mathrm{mg} \mathrm{kg}^{-1}\right.$ or $\left.\mathrm{L}^{-1}\right)$, is the concentration of soil or water contaminants; I (kg day ${ }^{1}$ ), is water or soil intake in children or adults; AF, is the absorption factor in the gastrointestinal tract wherein agreement with oral exposures the value of 1 is used (HC, 2014); Dh, hours of exposure per day (0-16); Dd, days of exposure in a week (0-7); Dw, weeks of exposure in a year $(0-52) ; \mathrm{BW}(\mathrm{kg})$ corporal individual weight.

\section{Risk characterization}

The risks by exposure to soil and water were estimated by integrating the results of the toxicity assessment in each source and comparing them with tolerable daily intake (TDI) (HC, 1995) or also named reference dose (RfD) (USEPA, 2017) to obtain the hazard quotient, which is defined with Equation 3:

$$
\mathrm{HQ}=\frac{\sum \text { Doses }}{\mathrm{RfD}}
$$

The following RfD doses were compared in this research: $0.03 \mathrm{mg} \mathrm{kg}^{-1} \mathrm{day}^{-1}$ (HC, 1995), $0.1 \mathrm{mg} \mathrm{kg}^{-1} \mathrm{day}^{-1}$ (USEPA, 2017), $0.5 \mathrm{mg} \mathrm{kg}^{-1} \mathrm{day}^{-1}$ (EFSA, 2015).

It is considered to be a potential human health risk when HQ is greater than 0.2.

\section{Statistical methods}

Concentrations and calibration curves were processed using calculus sheets of Microsoft Excel, 2016. The dose and hazard quotient was performed with the software Risk Calculation Tools (CIDA, 2009). In addition for exposure assessment were calculated significant differences to associate the consumption of contaminated water with herbicides and the suffering from diseases were analyzed using StatCalc tables $2 \times 2 \times \mathrm{N}$ from statistical software Epi Info 7.2, 2017.

\section{Results and discussion}

The selected communities are shown in Figure 1. In method validation by calibration curves, a correlation coefficient $\left(\mathrm{R}^{2}\right)$ of 0.994 was obtained for glyphosate whereas that for AMPA was 0.9917. Retention times were $8.3 \mathrm{~min}$ and $26.5 \mathrm{~min}$ for glyphosate and AMPA, respectively. 


\section{Hazard identification}

During the sampling period, herbicide was applied 3 times in Saucobe and in La Esquina, and 2 times in Colonia Soto and in Sebampo; in the other sampling points no weed problems were presented and only one application was recorded. A total of 90 results of glyphosate and AMPA from 45 samples (15 for irrigation water, 15 for well water and 15 from soil); where, $70 \%$ of the samples were positive for AMPA; these results are in agreement with IARC monograph (2016) which mention that are mayor percentage of positive samples of AMPA in superficial waters. For glyphosate, the samples showed concentrations lower than $5 \mu \mathrm{g} \mathrm{L}^{-1}$ whereas those for AMPA were from 15-342.5 $\mu \mathrm{g} \mathrm{L}^{-1}$ or $\mu \mathrm{g} \mathrm{g}^{-1}$ (Table 1).

Table 1. Glyphosate and AMPA concentrations in water and soil samples in different communities of Valle del Mayo, Sonora, Mexico

\begin{tabular}{|c|c|c|c|c|c|}
\hline \multirow[b]{2}{*}{ Date } & \multirow{2}{*}{$\begin{array}{l}\text { Valle del Mayo } \\
\text { Community }\end{array}$} & \multirow[b]{2}{*}{ Herbicide } & \multicolumn{3}{|c|}{ Concentrations in environmental samples } \\
\hline & & & $\begin{array}{c}\text { Superficial } \\
\text { water }\left(\mu \mathrm{g} \mathrm{L}^{-1}\right)\end{array}$ & $\begin{array}{c}\text { Well water } \\
\left(\mu \mathrm{g} \mathbf{L}^{-1}\right)\end{array}$ & $\begin{array}{c}\text { Soil } \\
\left(\mu g \mathbf{L}^{-1}\right)\end{array}$ \\
\hline February-March & 3 Carlos & $\begin{array}{c}\text { Glyphosate } \\
\text { AMPA }\end{array}$ & $\begin{array}{l}- \\
+\end{array}$ & $\begin{array}{l}- \\
-\end{array}$ & $\begin{array}{c}- \\
35.6\end{array}$ \\
\hline April-May & $\begin{array}{l}\text { Huatabampo } \\
\text { Colonia Soto }\end{array}$ & $\begin{array}{c}\text { Glyphosate } \\
\text { AMPA } \\
\text { Glyphosate } \\
\text { AMPA }\end{array}$ & $\begin{array}{c}- \\
18 \\
- \\
+\end{array}$ & $\begin{array}{l}- \\
+ \\
- \\
-\end{array}$ & $\begin{array}{c}- \\
36.76 \\
- \\
22.5 \\
\end{array}$ \\
\hline June-July & $\begin{array}{c}\text { Ramal } \\
\text { La Esquina }\end{array}$ & $\begin{array}{c}\text { Glyphosate } \\
\text { AMPA } \\
\text { Glyphosate } \\
\text { AMPA }\end{array}$ & $\begin{array}{c}- \\
+ \\
- \\
35.7\end{array}$ & $\begin{array}{l}- \\
+ \\
- \\
+\end{array}$ & $\begin{array}{c}- \\
- \\
- \\
342.75\end{array}$ \\
\hline August-September & $\begin{array}{l}\text { Saucobe } \\
\text { Colonia Soto } \\
\text { Moroncarit }\end{array}$ & $\begin{array}{c}\text { Glyphosate } \\
\text { AMPA } \\
\text { Glyphosate } \\
\text { AMPA } \\
\text { Glyphosate } \\
\text { AMPA }\end{array}$ & $\begin{array}{c}- \\
36.8 \\
- \\
+ \\
- \\
-\end{array}$ & $\begin{array}{l}- \\
+ \\
- \\
+ \\
- \\
-\end{array}$ & $\begin{array}{c}- \\
279.1 \\
- \\
89 \\
- \\
+ \\
\end{array}$ \\
\hline October-November & $\begin{array}{c}\text { Sebampo } \\
\text { Colonia Soto } \\
\text { La Esquina }\end{array}$ & $\begin{array}{c}\text { Glyphosate } \\
\text { AMPA } \\
\text { Glyphosate } \\
\text { AMPA } \\
\text { Glyphosate } \\
\text { AMPA }\end{array}$ & $\begin{array}{l}+ \\
+ \\
- \\
- \\
+ \\
-\end{array}$ & $\begin{array}{l}+ \\
+ \\
- \\
- \\
- \\
+\end{array}$ & $\begin{array}{c}- \\
56.7 \\
- \\
42 \\
- \\
298\end{array}$ \\
\hline December-January & Saucobe & $\begin{array}{c}\text { Glyphosate } \\
\text { AMPA }\end{array}$ & $\begin{array}{l}+ \\
-\end{array}$ & $\begin{array}{l}- \\
-\end{array}$ & $\begin{array}{c}- \\
56.3 \\
\end{array}$ \\
\hline February-March & $\begin{array}{l}\text { La Esquina } \\
\text { Sebampo }\end{array}$ & $\begin{array}{c}\text { Glyphosate } \\
\text { AMPA } \\
\text { Glyphosate } \\
\text { AMPA }\end{array}$ & $\begin{array}{l}- \\
+ \\
- \\
+\end{array}$ & $\begin{array}{l}- \\
+ \\
- \\
-\end{array}$ & $\begin{array}{c}- \\
- \\
- \\
47\end{array}$ \\
\hline April-May & Saucobe & $\begin{array}{c}\text { Glyphosate } \\
\text { AMPA }\end{array}$ & $\begin{array}{l}- \\
-\end{array}$ & $\begin{array}{l}- \\
+\end{array}$ & $\begin{array}{c}- \\
159\end{array}$ \\
\hline
\end{tabular}

*Symbol (+) refers to having a signal $\leq 5 \mu \mathrm{g} \mathrm{L} \mathrm{L}^{-1}$ for glyphosate and $\leq 15 \mu \mathrm{g} \mathrm{L}^{-1}$ for AMPA. Symbol (-) indicates that no signal was produced in the retention time 
The positive samples (60\%) for AMPA in the private wells maintained the following characteristics: built scarcely a few meters $(6-8 \mathrm{~m})$ from drains or irrigation canals covered by stone, brick or cement and excavated from 3-6 $\mathrm{m}$ in depth, which infers infiltration (Fig. 2). The results proved that glyphosate degrades rapidly although its presence in soil could reach groundwater by lixiviation (IARC, 2016).

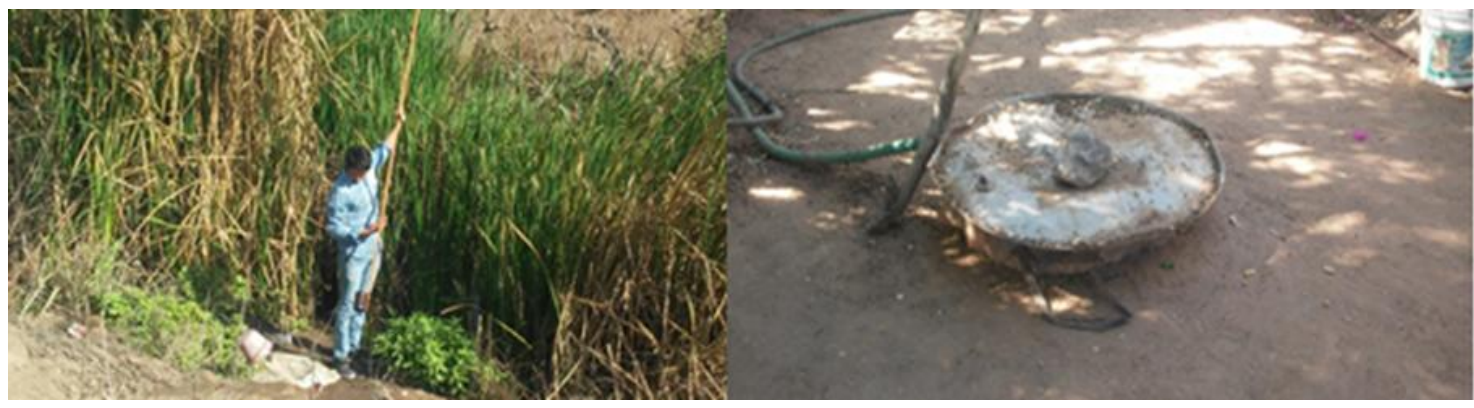

Figure 2. Photographs of private wells in the selected sites of Valle del Mayo, Sonora, Mexico (right: La Esquina private well, left: Saucobe private well)

Exposure to glyphosate at a dose of $300 \mathrm{mg} \mathrm{kg}^{-1}$ causes severe toxicity signs; a dose from 1000 to $5000 \mathrm{mg} \mathrm{kg}^{-1}$ causes death. The maximum permissible glyphosate concentration is different in drinking water depending on the country $\left(700 \mu \mathrm{g} \mathrm{L}^{-1}\right.$ in the U.S.A; $280 \mu \mathrm{g} \mathrm{L}^{-1}$ in Canada; $10 \mu \mathrm{g} \mathrm{L}^{-1}$ in Australia) (Laubli et al., 2016). With respect to the glyphosate concentration found $\left(\leq 5 \mu \mathrm{g} \mathrm{L} \mathrm{L}^{-1}\right)$, the detection limit of the method used in this study could be improved.

\section{Exposure evaluation}

Among the participants of the cohort study $(n=64)($ Fig. 3), $40 \%$ of those surveyed came from the Mayo indigenous ethnic group. Age range oscillated from 15 to 81 years old; the maximum level of studies registered were secondary school and $43 \%$ of the participants were low-average socioeconomic status. As to occupation, $18.75 \%$ of the workers surveyed were brick makers, $15.63 \%$ agricultural laborers and the rest were housewives and students. As for water use, $23.81 \%$ used drain water for domestic activities; $10.94 \%$ drain water for drinking; $53.7 \%$ private well water for domestic activities; and $37.5 \%$ private well water for drinking. Brick makers used irrigation drain water for making the bricks. Housewives $(22 \%)$ mentioned their children used drain and canal water for recreational activities.

The surveyed population declared (we verify with the prescriptions of the participants) having diabetes, obesity, hypertension; and dermatological, gastrointestinal and respiratory problems, among others (Fig. 4). Individuals, who expressed water consumption from private wells, recorded greater frequency in getting sick $(p \leq 0.01)$. With respect to the correlation between water consumption from private wells and frequent diseases, statistical significance was found with diabetes $(p \leq 0.03)$ and hypertension $(p \leq 0.004)$. Concerning these results is necessary to take into account that the place where these people live is agricultural and they may be exposed to a large number of agrochemicals, which are used in this area. Arrebola et al. (2015) have demonstrated that individuals with obesity, exposure to high levels of certain persistent organic contaminants, were associated with the risk of developing hypertension, 
independently of other factors, such as age, tobacco or alcohol consumption. Moreover, the high risks of these contaminants doubled this risk. The glyphosate applied in the drains of the Valley is a mix with tordon at $1.5 \%$ of the total formulated; mixtures can be more harmful to human health (Hernández et al., 2013).

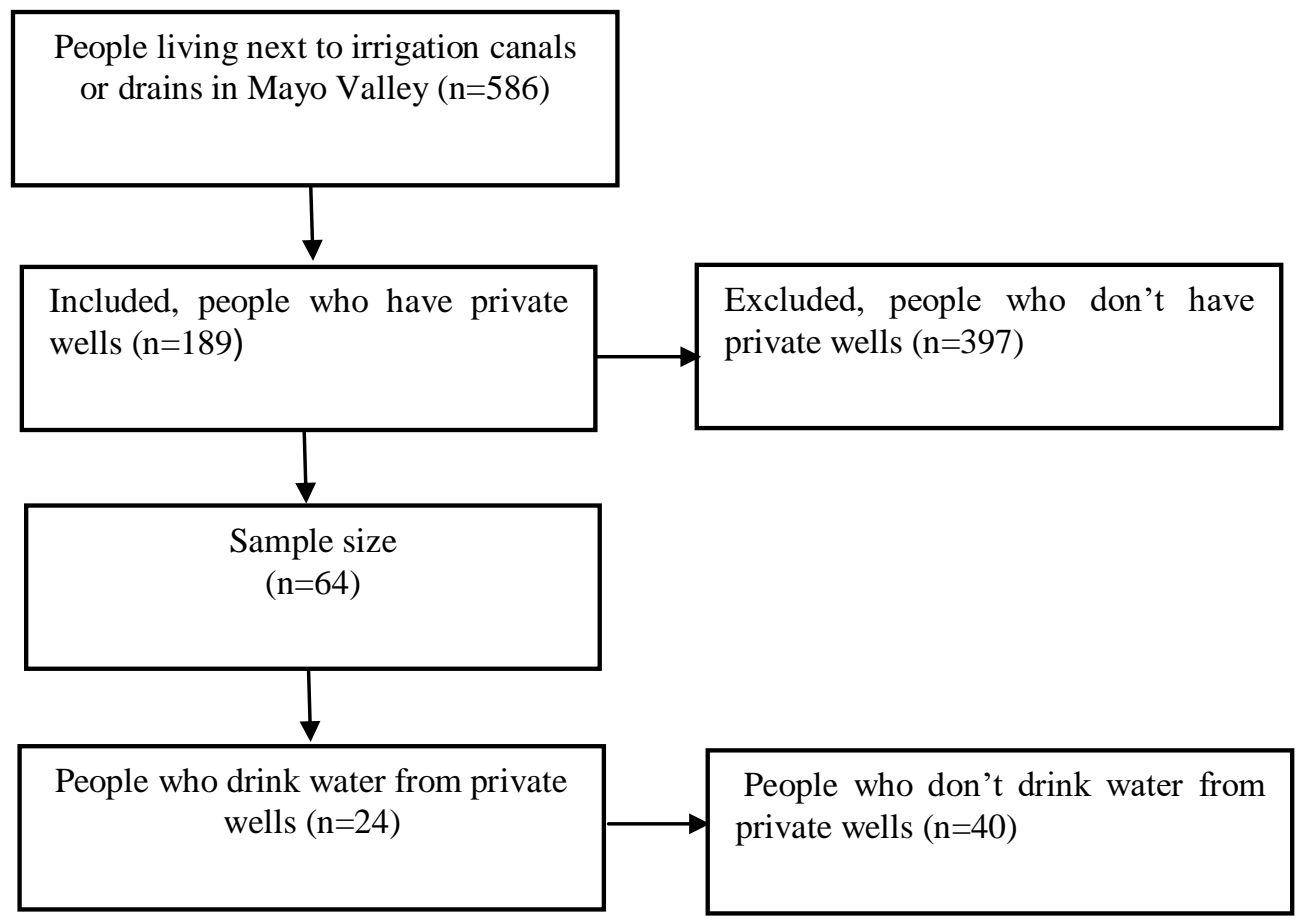

Figure 3. Systematic selection of the inclusion and exclusion criteria

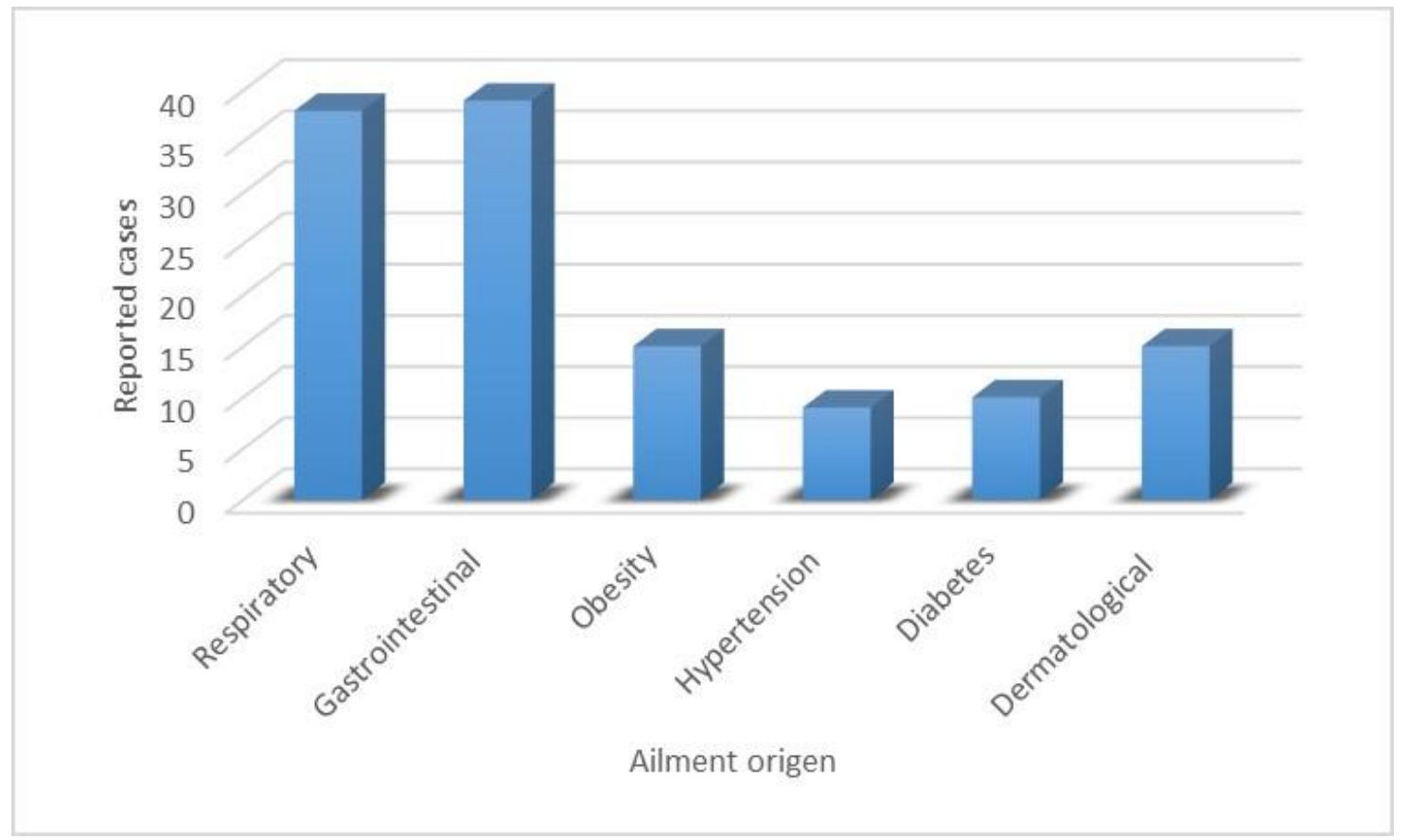

Figure 4. Most common diseases between the population of Valle del Mayo, Sonora, Mexico 
Swanson et al. (2014) made a correlation between glyphosate application and chronic diseases. The diseases with statistical significance were autism, thyroid cancer, senile dementia; significance was also observed with incidence and prevalence of diabetes, obesity, pancreas and kidney cancer and hypertension with a correlation lower than $90 \%$, different from the present research where hypertension recorded a high correlation.

Among the fresh vegetables most consumed by the individuals in the communities, were lettuce, squash, carrot, cucumber, chard or purslane.

\section{Toxicity assessment}

The gastrointestinal absorption is the quotient of the fraction of chemical absorbed orally between the fraction absorbed in principal study. Different parameters, obtained from the survey, were considered to assess health risk by glyphosate and AMPA exposure, in agricultural laborers, brick makers, housewives, and children from 2 to 16 years old and toddlers. For each one of the different receptors, the following was taken into account: housewives washed clothes with well water, which they also used it to wash food before ingesting, implying oral and dermal contact. Children in the communities usually took baths and swim into drain water, and finally, agricultural laborers and brick makers drank water from the well and consumed food washed with well water. With respect to soil, intake was considered accidental, as well as dermal contact with soil and drain water (Table 2).

\section{Risk characterization}

This study obtained a hazard quotient of 0.39 and 0.22 for brick makers and agricultural laborers respectively using, according to the formula, an RfD of $0.03 \mathrm{mg}$ $\mathrm{kg}^{-1}$ day $^{-1}$, which determined the potential health risk for AMPA in Valle del Mayo populations.

In the past, different countries used to have standardized ADIs of $0.03 \mathrm{mg} \mathrm{kg}^{-1} \mathrm{day}^{-1}$ (HC, 1995), $1.75 \mathrm{mg} \mathrm{kg}^{-1} \mathrm{day}^{-1}$ (USEPA, 2009), $0.1 \mathrm{mg} \mathrm{kg}^{-1}$ day $^{-1}$ for glyphosate and AMPA (FAO and WHO, 2011). Currently, laws regulate different ADIs: $0.3 \mathrm{mg} \mathrm{kg}^{-1}$ day $^{-1}$ (APVM, 2017), $0.5 \mathrm{mg} \mathrm{kg}^{-1} \mathrm{day}^{-1}$ (EFSA, 2015). The hazard quotients obtained using EFSA regulation are shown in Table 3. These results indicate that no health risk hazard exists on the population of Valle del Mayo.

One of the concerns is that no sufficient regulations exist for AMPA. It the past was reported that there are not enough concentrations in the environment to consider it a health problem (HC, 1995). However, other studies in the literature, as well as the present, found AMPA concentrations in well water greater than those of glyphosate (Kolpin et al., 2006; Battaglin et al., 2014).

The regulations of different countries agreed to a wide range of acceptable daily intake (ADI) for glyphosate and AMPA of 0-1 mg kg-1 day ${ }^{-1}$ (FAO and WHO, 2016). Controversially, several regulations and organizations have emphasized that the glyphosate studies, which IARC have based on, were badly designed, so they cannot be used as evidence to prove its carcinogenic effects. Other agencies (USEPA and EFSA) clarified there was not enough proof to support glyphosate as probably carcinogenic, so they establish the herbicide as "probably does not cause cancer". Despite before the IARC publication, all these regulatory agencies had graded glyphosate as currently the most harmful considering a lower ADI (EFSA, 2016; USEPA, 2017; APVM, 2017). 
Table 2. Parameters considered in the different receptors exposed to glyphosate and AMPA

\begin{tabular}{|c|c|c|c|c|c|}
\hline \multirow[b]{2}{*}{ Parameters } & \multicolumn{5}{|c|}{ Exposed population } \\
\hline & $\begin{array}{c}\text { Brick } \\
\text { makers }\end{array}$ & $\begin{array}{c}\text { Agricultural } \\
\text { laborer }\end{array}$ & Housewife & Toddler & Children \\
\hline $\begin{array}{l}\text { Maximum glyphosate concentration in } \\
\text { private well water, drain and soil water (mg } \\
\left.\qquad \mathrm{L}^{-1}\right)^{* 1}\end{array}$ & \multicolumn{5}{|c|}{$0.5 \times 10^{-2}$} \\
\hline $\begin{array}{l}\text { Maximum AMPA concentration in private } \\
\text { well water }\left(\mathrm{mg} \mathrm{L}^{-1}\right)^{* 1}\end{array}$ & \multicolumn{5}{|c|}{$1.5 \times 10^{-2}$} \\
\hline $\begin{array}{l}\text { Maximum AMPA concentration in } \\
\text { agricultural drain water }\left(\mathrm{mg} \mathrm{L}^{-1}\right)^{* 1}\end{array}$ & \multicolumn{5}{|c|}{$3.7 \times 10^{-2}$} \\
\hline $\begin{array}{l}\text { Maximum AMPA concentration in soil (mg } \\
\left.\qquad \mathrm{g}^{-1}\right)^{* 1}\end{array}$ & \multicolumn{5}{|c|}{$34.3 \times 10^{-2}$} \\
\hline $\begin{array}{l}\text { Maximum glyphosate concentration in } \\
\text { vegetables }\left(\mathrm{mg} \mathrm{g}^{-1}\right)^{* 2}\end{array}$ & \multicolumn{5}{|c|}{$5.4 \times 10^{-7}$} \\
\hline $\begin{array}{c}\text { Maximum AMPA concentration in } \\
\text { vegetables }\left(\mathrm{mg} \mathrm{g}^{-1}\right)^{* 2}\end{array}$ & \multicolumn{5}{|c|}{$1.62 \times 10^{-6}$} \\
\hline $\begin{array}{l}\text { Intake water rate for adults and children (L } \\
\left.\text { day }^{-1}\right)^{* 3}\end{array}$ & 2.9 & 2.4 & 1.8 & 0.6 & 1 \\
\hline $\begin{array}{l}\text { Soil intake rate for adults and children (g } \\
\left.\text { day }^{-1}\right)^{* 3}\end{array}$ & 0.02 & 0.02 & 0.02 & 0.05 & 0.05 \\
\hline Dermal contact with water $\left(\mathrm{cm}^{2}\right)^{* 4}$ & 17640 & 3390 & 890 & 890 & 10140 \\
\hline Dermal contact with soil $\left(\mathrm{g} \mathrm{cm}^{2-1} \text { event- }^{1}\right)^{* 4}$ & \multicolumn{2}{|c|}{$1.1 \times 10^{-4}$} & $1.0 \times 10^{-4}$ & \multicolumn{2}{|c|}{$1.1 \times 10^{-4}$} \\
\hline Vegetable intake $\left(\mathrm{g} \mathrm{day}^{-1}\right)^{* 4}$ & \multicolumn{3}{|c|}{137} & 67 & 98 \\
\hline $\begin{array}{l}\text { Absorption factor for the gastrointestinal } \\
\text { tract }^{* 4}\end{array}$ & \multicolumn{5}{|c|}{1} \\
\hline No. of days in one week of exposure ${ }^{* 5}$ & \multicolumn{5}{|c|}{7} \\
\hline No. of weeks in one year of exposure ${ }^{* 5}$ & 40 & \multicolumn{4}{|c|}{52} \\
\hline Years of exposure ${ }^{* 6}$ & 42 & 40 & 45 & $0.58-4$ & 5 to 15 \\
\hline Corporal weight of receptor $(\mathrm{kg})^{* 7}$ & \multicolumn{3}{|c|}{$\begin{array}{ll} & 1 \\
& \\
\end{array}$} & 16.5 & 32.97 \\
\hline $\begin{array}{l}{ }^{* 1} \text { Maximum concentration found of the herb } \\
\text { Chromatography } \\
{ }^{* 2} \text { Concentration depending on the private we } \\
{ }^{* 3} \text { Exposure factors handbook (USEPA 2011) } \\
{ }^{* 4} \text { Health Canada's PQRA model } 2004 \text { (HC } 2 \\
{ }^{* 5} \text { Data provided by DDRRM (2017) } \\
{ }^{* 6} \text { Average number of years the receptor has } \\
{ }^{* 7} \text { Average weight expressed in the surveys }\end{array}$ & $\begin{array}{l}\text { ide determ } \\
\text { water reta } \\
\text { 12) } \\
\text { en living }\end{array}$ & $\begin{array}{l}\text { ned by High-P } \\
\text { ned in leafy ve }\end{array}$ & $\begin{array}{l}\text { Performance } \\
\text { egetables }\end{array}$ & Liquid & \\
\hline
\end{tabular}

With the assurance of the majority of the regulatory agencies worldwide that glyphosate is not hazardous to health, the Food and Agriculture Association (FAO) and the World Health Organization (WHO) agreed that due to its low toxicity, it is not necessary to establish a reference dose for glyphosate in food residues (FAO and WHO, 2016). This new regulation allows glyphosate-resistant genetically modified cultivations, which represent approximately $56 \%$ of glyphosate use worldwide (Benbrook, 2016). It is important to mention FAO reported that 795 millions of individuals in the world are undernourished, of which 780 million live in underdeveloped regions (FAO, 2015), which is why both the use of herbicides and the 
convenience of eradicating famine should weigh up improvement in agriculture production and possible health problems.

The position of glyphosate as probable carcinogenic was assessed by IARC with enough background evidence in animal experiments to grade it as such for humans. The monograph published by the IARC is a thorough global compilation of the main scientific research on glyphosate, which clearly showed that glyphosate was harmful to flora and fauna and could cause cancer to humans (IARC, 2015).

Table 3. Risk quotient per occupational exposure to glyphosate and AMPA

\begin{tabular}{|c|c|c|c|c|c|c|c|c|c|c|}
\hline \multirow{2}{*}{ Exposure matrix } & \multicolumn{2}{|c|}{ Brick makers } & \multicolumn{2}{|c|}{ Agricultural laborer } & \multicolumn{2}{|c|}{ Housewife } & \multicolumn{2}{|c|}{ Toddler } & \multicolumn{2}{|c|}{ Children } \\
\hline & Gly*1 & AMPA & Gly & AMPA & Gly & AMPA & Gly & AMPA & Gly & AMPA \\
\hline Soil & $1.09 \times 10^{-6}$ & $7.5 \times 10^{-5}$ & $1.09 \times 10^{-6}$ & $7.5 \times 10^{-5}$ & $1.09 \times 10^{-6}$ & $7.5 \times 10^{-5}$ & $1.5 \times 10^{-5}$ & $1.03 \times 10^{-3}$ & $7.5 \times 10^{-6}$ & $5.18 \times 10^{-5}$ \\
\hline Water & $2 \times 10^{-4}$ & $1.52 \times 10^{-3}$ & $1.7 \times 10^{-4}$ & $1.2 \times 10^{-3}$ & $1.28 \times 10^{-4}$ & $3.8 \times 10^{-4}$ & $1.8 \times 10^{-4}$ & $5.4 \times 10^{-4}$ & $5.8 \times 10^{-5}$ & $4.5 \times 10^{-4}$ \\
\hline Food & $1.02 \times 10^{-9}$ & $3.17 \times 10^{-9}$ & $1.02 \times 10^{-9}$ & $3.17 \times 10^{-9}$ & $1.06 \times 10^{-9}$ & $3.17 \times 10^{-9}$ & $2.11 \times 10^{-9}$ & $6.58 \times 10^{-9}$ & $1.55 \times 10^{-9}$ & $4.82 \times 10^{-9}$ \\
\hline Dermal & $1.48 \times 10^{-4}$ & $1.02 \times 10^{-2}$ & $7.9 \times 10^{-5}$ & $5.4 \times 10^{-3}$ & $6.7 \times 10^{-6}$ & $4.6 \times 10^{-5}$ & $1.18 \times 10^{-5}$ & $8.1 \times 10^{-4}$ & $6.7 \times 10^{-5}$ & $4.6 \times 10^{-3}$ \\
\hline TDI $^{* 2}$ & $3.5 \times 10^{-4}$ & $1.1 \times 10^{-2}$ & $7.8 \times 10^{-5}$ & $6.7 \times 10^{-3}$ & $1.4 \times 10^{-4}$ & $9.2 \times 10^{-4}$ & $2 \times 10^{-4}$ & $2.3 \times 10^{-3}$ & $2.1 \times 10^{-6}$ & $1.58 \times 10^{-4}$ \\
\hline Bathing in drains & & & & & & & & & $1.4 \times 10^{-4}$ & $5.6 \times 10^{-3}$ \\
\hline ADI $*^{3}$ & & & & & $0.5 \mathrm{~m}$ & $\mathrm{~g} \mathrm{~kg}^{-1}$ & & & & \\
\hline $\mathrm{HQ}^{* 4}$ & $7.1 \times 10^{-4}$ & $2.3 \times 10^{-2}$ & $1.57 \times 10^{-4}$ & $1.34 \times 10^{-2}$ & $2.7 \times 10^{-4}$ & $1.85 \times 10^{-3}$ & $4.16 \times 10^{-4}$ & $4.78 \times 10^{-3}$ & $2.7 \times 10^{-4}$ & $1.1 \times 10^{-2}$ \\
\hline
\end{tabular}

\section{Conclusions}

Currently, ADIs regulation for glyphosate and AMPA to compare the present quotients, unlikely health risk exists on the population of Valle del Mayo, Mexico. Therefore, these results using an ADI of $0.03 \mathrm{mg} \mathrm{kg}^{-1}$ day $^{-1}$ suggest a potential health risk due to glyphosate and AMPA in the agricultural laborers and brick makers of this region. The permissible reference dose of glyphosate and AMPA has a very large margin (0-1 mg kg${ }^{-1}$ day $\left.^{-1}\right)$ even traces in food are permissible according to current regulations. In addition, we determinate that water consumption from the private well near to irrigation canals correlated statistically with diabetes $(p \leq 0.03)$ and hypertension $(p \leq 0.004)$. It is necessary to develop more toxicity studies that indicate an accurate value to establish that the herbicide and its metabolite do not cause harm to the human beings in a short and long-term.

Acknowledgements. The authors declare no conflicts of interest. We are grateful to the staff at Centro de Investigación e Innovación Biotecnológica Agropecuaria y Ambiental of Instituto Tecnológico de Sonora for their hospitality while processing samples; to Distrito de Riego del Rio Mayo, especially to Yamil Bisher, José Baldenegro, and Manuel Delgado for their valuable support in sample collection and data for this research.

\section{REFERENCES}

[1] Amrhein, N., Schab, J., Steinrücken, H. C. (1980): The mode of action of the herbicide glyphosate. - Naturwissenschaften 67(7): 356-357. 
[2] Angelini, D. J., Moyer, R. A., Cole, S., Willis, K., Oyler, J., Dorsey, R. M., Salem, H. (2015): The pesticide metabolites paraoxon and malaoxon induce cellular death by different mechanisms in cultured human pulmonary cells. - International Journal of Toxicology 34(5) 433-441.

[3] Arrebola, J. P., Fernández, M. F., Martín-Olmedo, P. et al. (2015): Historical exposure to persistent organic pollutants and risk of incident hypertension. - Environ Res 138: 21723.

[4] APVM (Australian Pesticides and Veterinary Medicines Authority) (2017): Final regulatory position: Consideration of the evidence for a formal reconsideration of glyphosate. - https://apvma.gov.au/.

[5] Battaglin, W. A., Meyer, M. T., Kuivila, K. M., Dietze, J. E. (2014): Glyphosate and its degradation product AMPA occur frequently and widely in U.S. soils, surface water, groundwater, and precipitation. - JAWRA 50(2): 275-290.

[6] Benbrook, C. M. (2016): Trends in glyphosate herbicide use in the United States and globally. - Environmental Sciences Europe 28(3): 1-15.

[7] Cattani, D., de Liz Oliveira-Cavalli, V. L., Heinz-Rieg, C. E. et al. (2014): Mechanisms underlying the neurotoxicity induced by glyphosate-based herbicide in immature rat hippocampus: involvement of glutamate excitotoxicity. - Toxicology 5: 34-45.

[8] CDC (Centers of Disease Control and Prevention) (2017): Epi Info ${ }^{\mathrm{TM}}, 7.2$ - CDC, Atlanta GA.

[9] Chaufan, G., Coalova, I., Rios de Molina, M. C. (2014): Glyphosate commercial formulation causes cytotoxicity, oxidative effects, and apoptosis on human cells: differences with its active ingredient. - International Journal of Toxicology 33(1): 29-38.

[10] CIDA (Canadian International Development Agency) (2009): Risk Calculation Tools. The World Bank, Canada.

[11] Dill, G. M., Sammons, R. D., Feng, P. C. C., Kohn, F., Kretzmer, K., Mehrsheikh, M. B., Hohegger, J. L., Farmer, D. W., Haupfear, E. A. (2010): Glyphosate: Discovery, Development, Applications, and Properties. - In: Nandula, V. K. (ed.). Glyphosate Resistance in Crops and Weeds: History, Development, and Management, pp. 1-33. Wiley, Hoboken, NJ, USA.

[12] DOF (Diario Oficial de la Federación) (2014): PROY NOM-250-SSA1-2014: Agua para uso y consumo humano. Límites máximos permisibles de la calidad del agua y requisitos sanitarios que deben cumplir los sistemas de abastecimiento de agua públicos y privados, su control y vigilancia. Procedimiento sanitario de muestreo. http://dof.gob.mx/nota_detalle.php?codigo=5356607\&fecha=15/08/2014.

[13] EFSA (European Food Safety Authority) (2015): EFSA explains risk assessment: glyphosate.

https://www.efsa.europa.eu/sites/default/files/corporate_publications/files/efsaexplainsgly phosate151112en.pdf.

[14] FAO (Food and Agriculture Organization of the United Nations) (2015): Pesticide Residues in Food. Meeting the 2015 international hunger targets: taking stock of uneven progress. - http://www.fao.org/3/a-i4646e.pdf.

[15] FAO (Food and Agriculture Organization of the United Nations) and WHO (Word Health Organization) (2011): Pesticide residues in food 2011 Toxicological evaluations. http://apps.who.int/iris/bitstream/10665/75147/1/9789241665278_eng.pdf.

[16] FAO (Food and Agriculture Organization of the United Nations) and WHO (World Health Organization) (2016): Meeting on Pesticide Residues (JMPR). http://www.who.int/foodsafety/jmprsummary2016.pdf.

[17] Gasnier, C., Dumont, C., Benachour, N., Clair, E., Chagnon, M. C., Seralini, G. E. (2009): Glyphosate-based herbicides are toxic and endocrine disruptors in human cell lines. - Toxicology 262: 184-191.

[18] Haas, C. N., Rose, J. B., Gerba, C. P. (1999): Quantitative microbial risk assessment. $1^{\text {st }}$. ed. - John Wiley \& Sons, Inc., New York. 
[19] HC (Health Canada) (1995): Guidelines for Canadian Drinking Water Quality Guideline Technical Document: Glyphosate. - https://www.canada.ca/en/healthcanada/services/publications/healthy-living/guidelines-canadian-drinking-water-qualityguideline-technical-document-glyphosate.html\#a1.

[20] HC (2012): Federal Contaminated Site Risk Assessment in Canada, Part I: Guidance on Human Health Preliminary Quantitative Risk Assessment (PQRA), Version 2.0. https://www.canada.ca/en/health-canada/services/environmental-workplace-

health/reports-publications/contaminated-sites/federal-contaminated-site-risk-assessmentcanada-part-guidance-human-health-preliminary-quantitative-risk-assessment-pqraversion-2-0.html.

[21] HC (2014): Health Canada Toxicological Reference Values (TRVs) and ChemicalSpecific Factors, version 2.0. - http://publications.gc.ca/collections/collection_2012/schc/H128-1-11-638-eng.pdf.

[22] Hernández, A. F., Parrón, T., Tsatsakis, A. M., Requena, M., Alarcón, R., LópezGuarnido, O. (2013): Toxic effects of pesticide mixtures at a molecular level: Their relevance to human health. - Toxicology 307: 136-145.

[23] IARC (International Agency of Research in Cancer) (2015): Glyphosate Monograph. http://monographs.iarc.fr/ENG/Monographs/vol112/mono112-10.pdf.

[24] INEGI (Instituto Nacional de Estadística y Geografía. Sonora) (2017): Información por entidad/Sonora.

http://cuentame.inegi.org.mx/monografias/informacion/son/default.aspx?tema=me\&e=26.

[25] Kolpin, D. W., Thurman, E. M., Lee, E. A. et al. (2006): Urban contributions of glyphosate and its degradate AMPA to streams in the United States. - Science Total Environment 354(2-3): 191-7.

[26] Laubli, M., Brand, B., Aeschlimann, A., Kappes, S. (2016): Glyphosate and AMPA in drinking water: determination using ion chromatography with pulsed amperometric detection. - The Application Notebook 6: 697-698.

[27] Ma, J. And Li, X. (2015): Alteration in the cytokine levels and histopathological damage in common carp induced by glyphosate. - Chemosphere 128: 293-298.

[28] Mañas, F., Peralta, L., Raviolo, J. et al. (2009): Genotoxicity of AMPA, the environmental metabolite of glyphosate, assessed by the Comet assay and cytogenetic tests. - Ecotoxicology Environmental Safety 2(3): 834-837.

[29] Mota, A., Mena, K. D., Soto-Beltran, M., Tarwater, P. M., Chaidez, C. (2009): Risk assessment of cryptosporidium and giardia in water irrigating fresh produce in Mexico. Journal of Food Protection 72(10): 2184-2188.

[30] Myers, J. P., Antoniou, M. N., Blumberg, B. et al. (2016): Concerns over use of glyphosate-based herbicides and risks associated with exposures: a consensus statement. - Environmental Health 15(19): 1-13.

[31] Nawaz, A., Razpotnik, A., Rouimi, P., de Sousa, G., Cravedi, J. P., Rahmani, R. (2014): Cellular impact of combinations of endosulfan, atrazine, and chlorpyrifos on human primary hepatocytes and HepaRG cells after short and chronic exposures. - Cell Biology and Toxicology 30: 17-29.

[32] NPIC (National Pesticide Information Center) (2015): Glyphosate General Fact Sheet. http://npic.orst.edu/factsheets/glyphogen.html.

[33] Olivo, V. E., Tansini, A., Carasek, F. et al. (2015): Rapid method for determination of glyphosate in groundwater using high performance liquid chromatography and solidphase extraction after derivatization. - Revista Ambiente y Agua 10(2): 286-297.

[34] Parrón, T., Requena, M., Hernández, A. F., Alarcón, R. (2014): Environmental exposure to pesticides and cancer risk in multiple human organ systems - Toxicology Letters 230: 157-165.

[35] Peruzzo, P. J., Porta, A. A., Ronco, A. E. (2008): Levels of glyphosate in surface waters, sediments and soils associated with direct sowing soybean cultivation in north pampasic region of Argentina. - Environ Poll 156: 61-66. 
[36] Portier, C. J., Armstrong, B. K., Baguley, B. C. et al. (2016): Differences in the carcinogenic evaluation of glyphosate between the International Agency for Research on Cancer (IARC) and the European Food Safety Authority (EFSA). - Journal Epidemiology Community Health 70(8): 741-745.

[37] Quarles, W. (2012): Brave new world systemic pesticides and genetically engineered crops. - IPM Practitioner 33(3/4): 1-13.

[38] Samsel, A., Seneff, S. (2015): Glyphosate, pathways to modern diseases III: Manganese, neurological diseases, and associated pathologies. - Surgery Neurology International 6: 45 .

[39] Shuval, H., Lampert, Y., Fattal, B. (1997): Development of a risk assessment approach for evaluating wastewater reuse standards for agriculture. - Water Science and Technology 35(11-12): 15-20.

[40] Swanson, N., Leu, A., Abrahamson, J., Wallet, B. (2014): Genetically engineered crops, glyphosate and the deterioration of health in the United States of America. - Journal Organic Systems 9(2): 6-36.

[41] USEPA (U. S. Environmental Protection Agency) (1989): Risk Assessment Guidance for Superfund Volume I Human Health Evaluation Manual. - USEPA. EPA/540/1-89/002, Cincinnati $\mathrm{OH}$.

[42] USEPA (2009): Human-Health Assessment Scoping Document in Support of Registration Review: Glyphosate. - U. S. Environmental Protection Agency, Office of Prevention, Pesticides, and Toxic Substances, Office of Pesticide Programs, U. S. Government Printing Office, Washington, DC.

[43] USEPA (2011): Exposure Factors Handbook: 2011 Edition. - EPA/600/R-09/052F, Washington DC.

[44] USEPA (2015): Table of Regulated Drinking Water Contaminants. http://www.epa.gov/your-drinking-water/table-regulated-drinking-watercontaminants\#one.

[45] USEPA (2017): Glyphosate; CASRN 1071-83-6. - https://www.epa.gov/iris. 